\title{
Mycobacterium kansasii: its presentation, treatment and outcome in HIV infected patients
}

\author{
G Rooney, M R Nelson, B Gazzard
}

\begin{abstract}
Aim-To report the clinical significance and treatment of Mycobacterium kansasii infection in the context of HIV disease.

Designlmethods-Retrospective case review of all isolates of $M$ kansasii until June 1994.

Results-Ten cases of $M$ kansasii were isolated. All but one patient with this infection had clinical symptoms compatible with generalised infection. The majority had chest infections with the organism isolated on induced sputum but not routine sputum. All isolates were sensitive to ethambutol and nine of 10 to rifampicin. All isolates were resistant to isoniazid and pyrazinamide.

Conclusion-M kansasii is a pathogen in HIV infected patients and should be treated when isolated. Treatment should be with rifampicin and ethambutol but not isoniazid, as has been recommended previously.

(F Clin Pathol 1996;49:821-823)
\end{abstract}

Keywords: Mycobacterium kansasii, HIV infection.

Atypical mycobacteria are widespread in the environment and cause both local and disseminated disease. Prior to the HIV epidemic, pulmonary disease due to Mycobacterium kansasii has been most commonly reported in the USA and Western Europe, particularly in those with pre-existing lung pathology. ${ }^{1}$ When found disseminated $M$ kansasii infection was often associated with pancytopenia and immunosuppressive therapy. ${ }^{2}$ Contamination of clinical samples was well recognised, and led some authors to specify strict criteria before a diagnosis of $M$ kansasii infection could be made. ${ }^{3}$ However, the suggestion that $M$ kansasii is virtually never a contaminant and that isolation from respiratory cultures is correlated with pulmonary disease has become more accepted with the advent of the HIV epidemic. ${ }^{45}$

With the rising prevalence of HIV infection there has been an increase in the number of reports of all the mycobacterial diseases, but the proportion of patients developing $M$ kansasii infection remains small relative to those for Mycobacterium tuberculosis and Mycobacterium avium complex. ${ }^{67}$

\section{Methods}

A retrospective case review was undertaken on all HIV seropositive patients identified by the microbiology department as having $M$ kansasii isolated from clinical specimens. AIDS was diagnosed according to the CDC classification in use at the time of study. ${ }^{8}$

Patients presenting to our unit with pyrexia routinely have blood cultures taken. In addition, if the CD4 count is less than 100 cells $/ \mathrm{mm}^{3}$, blood cultures for mycobacteria are performed using a BACTEC 13A radiometric system. Patients with diarrhoea are asked to provide at least three stool specimens, examination of which includes that for mycobacteria If respiratory symptoms are present sputum samples are sent for microscopy and culture. If Pneumocystis carinii pneumonia is suspected an induced sputum is performed, which is always cultured for mycobacteria. All radiographs are reviewed independently by medical stafi within the department of radiology.

When mycobacteria are isolated sensitivity testing is performed using both the resistance ratio $^{9}$ and radiometric ${ }^{10}$ methods. In the resistance ratio method the minimum inhibitory concentration of the test strain is compared with the modal average results of several control strains using the same batch of medium. The radiometric method is similar in principle but the medium is liquid. This allows for a more rapid growth and for the detection to be automated.

Based on criteria used by Levine et al, ${ }^{11}$ patients were defined as having definite pulmonary $M$ kansasii infection if symptomatic for more than two weeks (fever, cough, dyspnoea), chest $x$ ray changes suggestive of infiltration or cavitation, and two positive sputum cultures. Possible pulmonary $M$ kansasii infection was diagnosed if only one culture was positive. Disseminated disease was defined as isolation of $M$ kansasii from tissue other than lungs, skin, cervical or hilar lymph nodes.

\section{Results}

Ten cases of $M$ kansasii were isolated between January 1992 and June 1994 (table 1). Only one case occurred in 1992 and one in 1993, the rest being diagnosed in 1994. No case of $M$ kansasii was found prior to 1992. All but one patient experienced clinical symptoms compatible with generalised disease. Six had confirmed disseminated infection with positive blood cultures. The remaining four had positive induced sputum cultures, of which three could be defined as having definite pulmonary infection, and one had a diagnosis of possible infection. ${ }^{11}$ In none of the six patients who had a positive induced sputum was $M$ kansasii isolated on routine sputum examination, although at least two specimens 
Table 1 Clinical and micrbiological data of patients with Mycobacterium kansasii infection

\begin{tabular}{|c|c|c|c|c|c|c|c|c|}
\hline $\begin{array}{l}\text { Patient } \\
\text { number }\end{array}$ & $\begin{array}{l}\text { Months } \\
\text { since first } \\
\text { AIDS } \\
\text { diagnosis }\end{array}$ & $\begin{array}{l}\text { CD4 count at } \\
\text { time of } \\
\mathrm{M} \text { kansasii } \\
\text { isolation } \\
\left(\text { cells } / \mathrm{mm}^{3}\right)\end{array}$ & $\begin{array}{l}\text { Presenting } \\
\text { symptoms and } \\
\text { signs }\end{array}$ & $\begin{array}{l}\text { Concurrent } \\
\text { opportunistic } \\
\text { infections/tumours }\end{array}$ & $\begin{array}{l}\text { Source of } \mathrm{M} \text { kansasii } \\
\text { isolate }\end{array}$ & $\begin{array}{l}\text { Antimicrobial } \\
\text { sensitivities }\end{array}$ & Treatment & $\begin{array}{l}\text { Outcome from time of } \\
\mathrm{M} \text { kansasii isolation }\end{array}$ \\
\hline 1 & 55 & $2(1 \%)$ & $\begin{array}{l}\text { Fever } \\
\text { Malaise } \\
\text { Abscess }\end{array}$ & Oral candida & $\begin{array}{l}\text { Abscess } \\
\text { Blood }\end{array}$ & $\begin{array}{l}\text { Ethambutol } \\
\text { Ciprofloxacin }\end{array}$ & $\begin{array}{l}\text { Ethambutol } \\
\text { Clarythromicin } \\
\text { Ciprofloxacin }\end{array}$ & Died 4 months later \\
\hline 2 & 60 & $2(1 \%)$ & $\begin{array}{l}\text { Fever } \\
\text { Malaise } \\
\text { Cough } \\
\text { Anaemia }\end{array}$ & $\begin{array}{l}\text { Kaposi sarcoma } \\
\text { CMV retinitis }\end{array}$ & $\begin{array}{l}\text { Induced sputum }(\mathrm{n}=2) \\
\text { Blood }\end{array}$ & $\begin{array}{l}\text { Rifabutin/rifampicin } \\
\text { Ethambutol } \\
\text { Ciprofloxacin } \\
\text { Clofazamine }\end{array}$ & $\begin{array}{l}\text { Rifabutin } \\
\text { Ethambutol } \\
\text { Ciprofloxacin }\end{array}$ & $\begin{array}{l}\text { Alive at } 8 \text { months; } \\
\text { symptoms controlled; } \\
\text { negative induced } \\
\text { sputum and blood } \\
\text { cultures at } 2 \text { months }\end{array}$ \\
\hline 3 & 48 & $14(4 \%)$ & $\begin{array}{l}\text { Fever } \\
\text { Neurological }\end{array}$ & Listeria meningitis & $\begin{array}{l}\text { Stool } \\
\text { Blood }\end{array}$ & $\begin{array}{l}\text { Rifabutin/rifampicin } \\
\text { Ethambutol } \\
\text { Ciprofloxacin }\end{array}$ & $\begin{array}{l}\text { Rifabutin } \\
\text { Ethambutol } \\
\text { (stopped) } \\
\text { Clarythromicin } \\
\text { Clofazamine }\end{array}$ & $\begin{array}{l}\text { Died } 5 \text { months later of } \\
\text { overwhelming sepsis; } \\
\text { negative blood } \\
\text { cultures at } 3 \text { months }\end{array}$ \\
\hline 4 & 10 & $40(8 \%)$ & $\begin{array}{l}\text { Fever } \\
\text { Malaise } \\
\text { Cough } \\
\text { Hepatosplenon } \\
\text { Anaemia }\end{array}$ & $\begin{array}{l}\text { None } \\
\text { megaly }\end{array}$ & $\begin{array}{l}\text { Induced sputum }(n=1) \\
\text { Stool } \\
\text { Blood }\end{array}$ & $\begin{array}{l}\text { Rifabutin/rifampicin } \\
\text { Ethambutol } \\
\text { Ciprofloxacin } \\
\text { Clofazamine }\end{array}$ & $\begin{array}{l}\text { Rifampicin } \\
\text { Isoniazid } \\
\text { Ethambutol }\end{array}$ & $\begin{array}{l}\text { Alive at } 5 \text { months; } \\
\text { control of symptoms }\end{array}$ \\
\hline 5 & 18 & $2(1 \%)$ & $\begin{array}{l}\text { Fever } \\
\text { Malaise } \\
\text { Cough } \\
\text { Hepatomegaly } \\
\text { Anaemia }\end{array}$ & $\begin{array}{l}\text { Pseudomonas chest } \\
\text { infection }\end{array}$ & Blood & $\begin{array}{l}\text { Rifampicin } \\
\text { Ethambutol }\end{array}$ & $\begin{array}{l}\text { Rifabutin } \\
\text { Ethambutol } \\
\text { Clofazamine }\end{array}$ & $\begin{array}{l}\text { Alive at } 6 \text { months; } \\
\text { control of symptoms }\end{array}$ \\
\hline 6 & 17 & $1(1 \%)$ & $\begin{array}{l}\text { Fever } \\
\text { Cough } \\
\text { Anaemia }\end{array}$ & P carinii pneumonia & Blood & $\begin{array}{l}\text { Rifampicin } \\
\text { Ethambutol }\end{array}$ & $\begin{array}{l}\text { Rifabutin } \\
\text { Clofazamine } \\
\text { Ethambutol } \\
\text { (stopped) }\end{array}$ & $\begin{array}{l}\text { Alive at } 15 \text { months; } \\
\text { control of symptoms; } \\
\text { negative induced } \\
\text { sputum, BAL and blood } \\
\text { cultures at } 9 \text { months }\end{array}$ \\
\hline 7 & 26 & $16(4 \%)$ & $\begin{array}{l}\text { Fever } \\
\text { Malaise } \\
\text { Cough/ } \\
\text { dyspnoea } \\
\text { Anorexia }\end{array}$ & None & Induced sputum $(n=2)$ & $\begin{array}{l}\text { Rifampicin } \\
\text { Ethambutol }\end{array}$ & $\begin{array}{l}\text { Rifabutin } \\
\text { Ethambutol } \\
\text { Ciprofloxacin }\end{array}$ & $\begin{array}{l}\text { Alive at } 4 \text { months; } \\
\text { control of symptoms }\end{array}$ \\
\hline 8 & 24 & $18(2 \%)$ & $\begin{array}{l}\text { Fever } \\
\text { Malaise } \\
\text { Anaemia }\end{array}$ & $\begin{array}{l}\text { CMV retinitis } \\
\text { Lymphoma }\end{array}$ & Induced sputum $(n=1)$ & $\begin{array}{l}\text { Rifabutin/rifampicin } \\
\text { Ethambutol } \\
\text { Clarythromicin } \\
\text { Ciprofloxacin }\end{array}$ & $\begin{array}{l}\text { Rifabutin } \\
\text { Ethambutol } \\
\text { Clarythromicin }\end{array}$ & $\begin{array}{l}\text { Died at } 1 \text { month from } \\
\text { associated lymphoma }\end{array}$ \\
\hline 9 & 2 & $10(5 \%)$ & $\begin{array}{l}\text { Chest pain } \\
\text { Cough } \\
\text { Malaise }\end{array}$ & Kaposi sarcoma & Induced sputum $(n=2)$ & $\begin{array}{l}\text { Rifampicin } \\
\text { Ethambutol }\end{array}$ & $\begin{array}{l}\text { Rifabutin } \\
\text { Ethambutol } \\
\text { Ciprofloxacin }\end{array}$ & $\begin{array}{l}\text { Alive at } 19 \text { months; } \\
\text { intermittent positive } \\
\text { induced sputum }\end{array}$ \\
\hline 10 & 0 & $96(6 \%)$ & $\begin{array}{l}\text { Fever } \\
\text { Cough } \\
\text { Anaemia }\end{array}$ & Pcarinii pneumonia & Induced sputum $(n=2)$ & $\begin{array}{l}\text { Rifampicin } \\
\text { Ethambutol } \\
\text { Ciprofloxacin }\end{array}$ & $\begin{array}{l}\text { Rifabutin } \\
\text { Clarythromicin } \\
\text { Ciprofloxacin }\end{array}$ & $\begin{array}{l}\text { Alive at } 1 \text { month; } \\
\text { control of symptoms }\end{array}$ \\
\hline
\end{tabular}

from each patient were sent to the laboratory for culture. At the time of $M$ kansasii isolation, seven of 10 patients were receiving cotrimoxazole ( $960 \mathrm{mg}$ od).

In the six cases where positive induced sputum cultures were obtained, pulmonary symptoms were present. However, only two of the chest radiographs were felt to be abnormal. Patient 4 had evidence of cavitation and fibrosis and patient 10 had bilateral alveolar shadowing but at the same time was infected with $P$ carinii.

During the same study period 50 cases of $M$ avium complex infection were diagnosed, as were 33 cases of $M$ tuberculosis infection, of which 16 were extrapulmonary. The median CD4 at diagnosis of $M$ kansasii was 17 (mean 20; range 2-96) which was comparable with that for $M$ avium complex (mean 23; median 17 ; range $0-156$ ), but significantly lower than that for $M$ tuberculosis (mean 166; median 70; range 3-375).
Review of antimicrobial sensitivities (table 1) indicates that all isolates were sensitive to $\sigma$ ethambutol and nine of 10 were sensitive to $N$ rifampicin. All were resistant to isoniazid and pyrazinamide. Six isolates were tested against 0 ciprofloxacin and all were fully or partially sensitive.

All cases were treated initially with at least $\stackrel{\mathscr{\rho}}{+}$ two drugs to which their $M$ kansasii infection 0 was sensitive. By April 1994 three of the $10 \stackrel{\mathrm{D}}{\mathbb{D}}$ patients had died; $M$ kansasii infection is felt to $\Omega$ have contributed partially to two deaths, $\triangle$ although both patients had multiple, advanced AIDS related illnesses. Patient 8 had treatment 8 for $M$ kansasii withdrawn after one week and died within one month of disseminated lymphoma. The remainder were alive one to $15 \stackrel{?}{?}$ months after diagnosis.

\section{Discussion}

This report details a series of $M$ kansasii disease associated with HIV infection in the 
UK. Like infection with $M$ avium complex, in this study $M$ kansasii disease occurred in those with severe immunosuppression. Presentation was non-specific; fever and malaise were common, although specific symptoms were usual in patients with respiratory infection. In contrast with the experience of Levine et al ${ }^{11}$ chest radiographs were often normal in patients with pulmonary disease. This lack of cavitation and fibrosis has been noted in other series ${ }^{12-14}$ and presumably reflects the underlying level of immunosuppression.

In patients with AIDS, initial respiratory or gastrointestinal isolation of other atypical mycobacteriae is frequently followed by widespread dissemination of the infection. ${ }^{15}{ }^{16}$ Similarly, Levine et $a l^{11}$ found that in HIV infected patients when $M$ kansasii infection was left untreated, most cases resulted in progressive clinical deterioration, but if treatment of $M$ kansasii infection was undertaken documented clinical improvement resulted. All of our patients received treatment. Patient 9 was poorly compliant with treatment and continued to be symptomatic and to produce positive isolates. The others achieved good control of symptoms and no further isolates of $M$ kansasii were obtained. Thus, we would recommend that if $M$ kansasii is isolated, treatment should be commenced. If further samples yield positive cultures of $M$ kansasii, then treatment should be maintained indefinitely. If further samples fail to yield $M$ kansasii, decisions concerning further investigation or treatment will depend upon the clinical picture and the initial response to treatment.

From the antimicrobial sensitivities presented, we would continue to recommend the initial use of rifampicin/rifabutin and ethambutol as first line treatments. All patients in this series had isoniazid resistant $M$ kansasii, an observation seen partially or fully in a number of other reviews. ${ }^{511} 12$ Thus, in contrast to the recommendations of the American Thoracic Society ${ }^{17}$ it would seem sensible not to include isoniazid in a treatment regimen and that if use of a third drug is necessary, to consider one of the newer quinolones. Although only a limited number of isolates were tested against clofazamine $(n=2)$ and clarythromicin $(n=$ 1), as a result of the favourable sensitivities obtained, these drugs could also be considered in patients intolerant or failing first line treatment.

In reviewing previously reported in vitro sensitivity of $M$ kansasii to sulphur based drugs, sulphamethiazole has been recom- mended as a treatment option ${ }^{18}$ and has proved efficacious in HIV infected patients not responding to other treatment. ${ }^{19}$ However, in the dosage used in prophylactic treatment of $P$ carinii pneumonia sulphamethiazole seems to offer little protection against the development of $M$ kansasii infection.

1 Schraufnagel DE, Leech JA, Pollak B. Mycobacterium kansasii: colonisation and disease. Br $\mathcal{f}$ Dis Chest 1986; 80: $131-7$.

2 Engstrom PF, Dewey GC, Barrett O. Disseminated Mycobacterium kansasii infection. Successful treatment of a patient with pancytopenia. $A m \mathcal{F} M e d 1972 ; 52: 533-7$.

3 Ahn CH, McLarty JW, Ahn SS, Ahn SI, Hurst GA. Diagnostic criteria for pulmonary disease caused by Mycobacterium kansasii and Mycobacterium intracellulare. $\mathrm{Am}$ Rev Respir Dis 1982;125:388-91

4 Wolinsky E. When is an infection disease? Rev Infect Dis 1981;3:1025-7.

5 Bamberger DM, Driks MR, Gupta MR, O'Connor MC, Jost PM, Neihart RE, et al. Mycobacterium kansasii among patients infected with the human immunodeficiency virus in Kansas City. Clin Infect Dis 1994;18:395-400.

6 Selik RM, Starcher ET, Curran JW. Opportunistic disease reported in AIDS patients: frequencies, associations, end bends. AIDS 1987;1:175-82.

7 Horsburgh CR, Selik RM. The epidemiology of disseminated non-tuberculous mycobacterial infection in the Acquired Immunodeficiency Syndrome (AIDS). Am Rev Respir Dis 1989;139:4-7.

8 Centers for disease control and prevention. 1993 revised classification system for HIV infection and expanded surveillance case definition for AIDS among adolescents and adults. $M M W R$ 1992;41:1-19.

9 Collins $\mathrm{CH}$, Grange JM, Yates MD. Organization and practice in tuberculosis bacteriology. London: Butterworths, 1985.

10 Vinke G, Yegers O, Vanachter H, Jenkins PA, Butzler JP. Rapid susceptibility testing of Mycobacterium tuberculosis by a radiometric technique. $\mathcal{f}$ Antimicrob Chemothe 1982;10:351-4

11 Levine B, Chaisson RE. Mycobacterium kansasii: a cause of treatable pulmonary disease associated with advanced Human Immunodeficiency Virus (HIV) infection. Ann Intern Med 1991;114:861-8.

12 Sherer R, Sable R, Sonnenberg M, Cooper S, Spencer P, Schwimmer $S$, et al. Disseminated infection with Mycobacterium kansasii in the acquired immunodeficiency syndrome. Ann Intern Med 1986;105:710-12.

13 Valainis GT, Cardona LM, Greer DL. The spectrum of Mycobacterium kansasii disease associated with HIV-1 infected patients. F Acquired Immune Defic Syndr Hum Retrovirol 1991;4:516-20.

14 Valaris GT. Mycobacterium kansasii infection [letter]. Ann Intern Med 1991;115:496-7.

15 Hawkins CC, Gold JWM, Whimbey E, Kiehn TE, Brannon $\mathrm{P}$, Cammarata R, et al. Mycobacterium avium complex infections in patients with the acquired immunodeficiency syndrome. Ann Intern Med 1986;105:184-8.

16 Chin DP, Hopewell PC, Yajko DM, Vittinghoff E Horsburgh CR, Hadley WK, et al. Mycobacterium avium complex in the respiratory or gastrointestinal tract and the risk of $\mathrm{M}$. avium complex bacteraemia in patients with human immunodeficiency virus infection. $\mathcal{F}$ Infect Dis 1994;169:289-95.

17 Mycobacterioses and the acquired immunodeficiency syndrome. Joint Position Paper of the American Thoracic Society and the Centers for Disease Control. Am Rev Respir Dis 1987;136:492-6.

18 Carpenter JL, Parks JM. Mycobacterium kansasii infections in patients positive for the human immunodeficiency virus. Rev Infect Dis 1991;13:789-96.

19 Ahn CH, Wallace RJ, Steele LC, Murphy DI. Sulphonamide containing regimens for disease caused by rifampicin 135:10-16. 